\title{
ANALYSIS OF FUEL QUALITY EFFECT ON THE LIFE TIME FROM HIGH-PRESSURE PUMP OF ENGINE MTU 12 V 4000 M 71
}

\author{
Sutrisno, Wawan Kusdiana, Anton Nugroho, Abdul Rahman \\ Indonesian Naval Technology College, STTAL \\ Bumimoro-Morokrembangan, Surabaya 60178, Indonesia
}

\begin{abstract}
Fuel is one of the important components in the combustion process. A good fuel is a clean fuel where the fuel is colorless, watery, has a high flash point, it can ignite spontaneously at a temperature of $350^{\circ} \mathrm{C}$, and has a specific gravity of about $0.82-0.86$. On the other hand, KRI Kelabang-826 is an Indonesian republic warship that functions as a patrol boat. This causes the ship to have a medium duty engine, the MTU $12 \mathrm{~V} 4000 \mathrm{M} 71$ engine. This engine itself is a sophisticated engine because it uses common rail technology with a High-Pressure Pump as the supplying pump. This pump is very susceptible to damage, this is proven by not achieving the life time of the High-Pressure Pump which is 7500 Running Hours or once a W5level maintenance. This is caused by poor quality of fuel, where the fuel used contains water and impurities. Therefore, the preventive ways are needed in order to achieve the life time of this High-Pressure Pump component.
\end{abstract}

Keywords: Fuel Quality, MTU 12 V 4000 M 71, High-Pressure Pump, and Condor Class.

\section{Introduction}

One type of diesel engine fuel is diesel fuel. Material diesel fuel is a refined fuel oil from petroleum raw, where this fuel is clear brown yellow. HSD is a type of diesel fuel used for diesel engines that have a Cetane number of 45 . Generally, that engine using HSD fuel is engine injection pump system and injection electronics.

The two things contained in fuel are dirt and water. Fuel containing water will give an unfavorable influence for engine components, especially the fuel system itself. For machines with a common rail system (4000 series) high water content will cause damage to high pressure pumps (High Pressure Pump) and injectors. the amount of impurities in the fuel affects the fuel filter replacement period and decreases engine performance.

KRI Kelabang-826 is an Indonesian republic warship which was made in East Germany on May 28, 1971. This ship began to enter the Indonesian Navy on May 31,1995 . This ship functions are as a patrol boat. This ship itself is under the patrol force of the 1st Western Fleet. This ship has high number of mobility that forces this ship to use a medium duty engine that is the MTU 12 V 4000 M 71 engine.

The MTU 12 V $4000 \mathrm{M} 71$ diesel is a modern technology diesel that has 2,480 BHP power. MTU comes from German which stands for "Motoren Turbinen Union" which means the combination of engine and turbine. This type of MTU engine 4000 is a new generation of diesel engine that was created in order to answer the challenges/ rules required for diesel engines in accordance with IMO Reg 13 Annes VI of MARPOL 73/78 about the environment, for that we need a technology called the common rail.

The common rail system was first developed by Robert Huber from Switzerland in 1960 . The common rail understanding is a fuel system governed by the ECU (Engine Control Unit) to regulate the quantity and pressure of the fuel so that perfect combustion can occur, so as to maximize efficiency in fuel use. There are several advantages of the Common Rail system, including the lack of used gas fumes and noise, low exhaust emissions, especially Nitrogen Oxide emissions (NOx), and fuel efficiency. In order to achieve these conditions, a component called the HighPressure Pump is needed.

High-Pressure Pump has a pressure of up to 1400 Bar and has injection capability and fuel injection timing that is regulated electronically by the Engine Control Unit (ECU). To meet the above requirements, a clean fuel is needed from dirt, water content and so on before entering the combustion system. there are currently many problems with the High-Pressure Pump component. This is a big problem because this component is a vital component in supporting the continuity of the common rail 
system. In other words, if this component is damaged the engine performance will decrease until the engine stops. So that why the need for good fuel is needed to support the performance of the engine with a common rail system in order to obtain maximum efficiency. So, it is important to know the relation of the fuel quality that used in KRI Kelabang-826 with the effect to High Pressure Pump Engine MTU 12 V 4000 M 71.

\section{MATERIALS AND METHODELOGY.}

\subsection{Diesel Fuel}

Diesel engine fuel consists mainly of compounds hydrocarbons and nonhydrocarbon compounds. Hydrocarbon compounds which can be found in diesel fuel including paraffin, naphthenic, olefins and aromatics. Whereas for nonhydrocarbon compounds consist of compounds containing non-metallic elements, namely $\mathrm{S}, \mathrm{N}, \mathrm{O}$ and elements metals such as vanadium, nickel and iron. Machines with high speed (> $1000 \mathrm{rpm}$ ) require materials with certain characteristics that are different from diesel oil.

HSD is a type of diesel fuel used for diesel engines that have a Cetane number of 45. Generally, that engine using HSD fuel is engine injection pump system and injection electronics. So, basically this fuel is intended for motor vehicles and as industrial equipment fuel. In addition, machines with fast rotation (> $1000 \mathrm{rpm}$ ) need fuel with certain different characteristics with diesel oil. The characteristics that are related are related to auto ignition (self-igniting ability), ease of flowing inside fuel lines, the ability to be atomized, the ability lubrication, heating value and other characters. Diesel fuel has the main properties, namely:

a. Colorless or only slightly yellowish and smelly.

b. Watery and non-volatile at normal temperatures.

c. Having a high flash point $\left(40^{\circ}\right.$ to $\left.100^{\circ} \mathrm{C}\right)$.

d. Burn spontaneously at $350^{\circ} \mathrm{C}$.

e. Having a density (density) around 0.82 -0.86 .

f. Able to cause large heat $(10,500 \mathrm{kcal} /$ $\mathrm{kg}$ ).

g. Has a sulfur content that is greater than fuel.

\subsection{Common Rail Technology}

Common rail system is a fuel system regulated or controlled by the ECU (Engine Control Unit) to regulate the quantity and pressure of the fuel so that combustion can occur perfect, so as to maximize the efficient use of materials burn, (Anto, 2015).

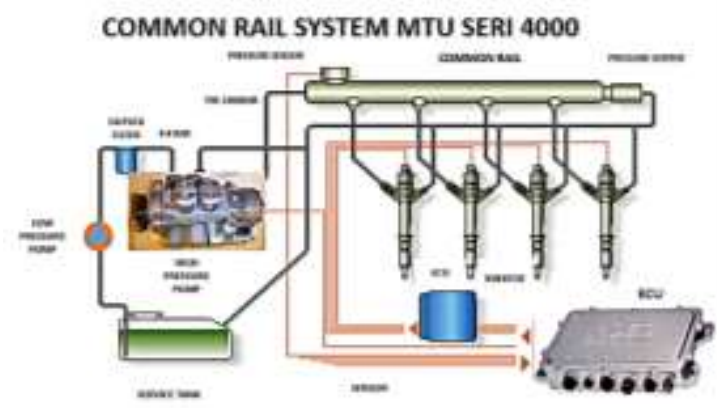

Figure. 1 Common Rail System MTU 4000 Series

If we talk about common rail, then we will not escape review of the function of the system. The function of common rail outline, among others:

a. To provide fuel to the engine.

b. To generate high pressure fuel that is needed and distribute it to each cylinder.

c. To inject fuel with the amount and time precise / precision injection.

\subsection{High Pressure Pump}

MTU engine type 4000 is a new generation diesel engine which was created in order to answer the challenges and rules that have been made Required for diesel engines in accordance with IMO Reg 13 Annes VI of MARPOL 73/78 about the environment. Common rail technology that is on MTU type 4000 is expected to answer all of these challenges above (Hidayat, 2008). This is because it has several advantages among others:

a. Lack of used gas smoke and noise.

b. Low exhaust emissions, especially Nitrogen Oxide emissions (NOx).

c. Fuel consumption system efficiency.

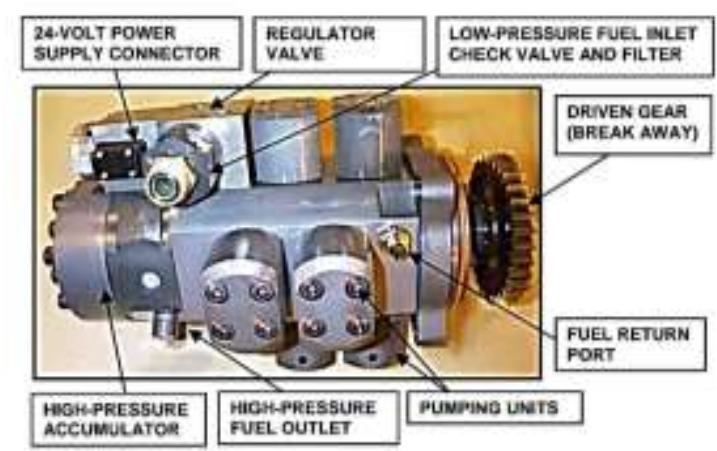

Figure. 2 High Pressure Pump

In simple terms, the common rail system can be interpreted as how to spray fuel in the amount and time precisely so that it can produce more fuel depletion perfect. 
Therefore, we use a pump call the HighPressure Pump (HP Pump) which has pressure up to 1400 Bar and fuel quantity will be set electronically by the Engine Control Unit (ECU). To fulfill the above requirements, it is needed clean fuel from dirt and water content before entering the combustion system. This is very necessary, due to High Pressure Pump pressure which reaches up to $1400 \mathrm{Bar}$ or reaches five times the normal injection pump pressure. Therefore, then filtering the fuel system must be smoother than 5 to 10 microns which on older machines is usually around 20 to with 25 microns. This fuel requirement is very important because it is wrong one function of the fuel is as the High-Pressure Pump itself with very High-Pressure conditions, (Detroit Diesel, 2001).

\subsection{Fuel Quality Standard from PERTAMINA}

Based on the Decree of the Minister of Energy and Mineral Resources Number 273.K / 10.01 / DJM.O/ 2013 dated March 4, 2013 for the type of Oil. Diesel Fuel (Solar) 48 has the following standard features:

a. Has a high cetane or RON number, which is between 45 up to 52 .

b. Having specifications must comply with Oil and Gas specifications in Indonesia.

c. Has a low water content so it does not cause corrosion on a diesel engine.

d. Has a low sulfur content so it is clean of deposition of dirt in the engine combustion chamber

e. Have the quality of fuel power that is sufficient heat, no may be excessive.

f. Can produce large power for diesel engines.

g. Did not get additives or chemical additives characterized by clear solar, there is no initial yellow color like gasoline and over time change the color of bright tea.

\subsection{Standard Specifications and Quality of Diesel Fuel (Solar)}

The use of diesel oil must be safe, not dangerous humans, not damaging machines, must be efficient in their use as well does not cause pollution to the environment. To give a guarantee standards (specifications) and quality of diesel fuel oils marketed domestically, the Indonesian government through a Decree Director General of Oil and Gas Number 28.K / 10 / DJM.T / 2016, February 24, 2016 provides restrictions as the table below.

Table 1. Fuel Characteristic Table

\begin{tabular}{|c|c|c|c|c|c|}
\hline \multirow{2}{*}{ NO } & \multirow{2}{*}{ KARAKTEFISTIK } & \multirow{2}{*}{ SATUAN } & \multicolumn{2}{|c|}{ BATASAM } & \multirow{2}{*}{$\begin{array}{c}\text { METOOE } \\
\text { U.J } \\
\text { ASTM } \\
\end{array}$} \\
\hline & & & MiN & MaKS & \\
\hline 1 & 2 & 3 & 4 & 5 & $E$ \\
\hline 1. & $\begin{array}{l}\text { Blangan celana / angka } \\
\text { cetana }\end{array}$ & & $\begin{array}{l}48 \\
45\end{array}$ & & $\begin{array}{l}0613 \\
04737\end{array}$ \\
\hline 2. & Berat jaris of $15^{f} \mathrm{C}$ & $\mathrm{Kg} / \mathrm{m}^{3}$ & 815 & 850 & $\begin{array}{l}\text { D } 12981 \\
04052\end{array}$ \\
\hline 3. & Viskosilas ge $400 \mathrm{C}$ & Iinzisec & 2,0 & 4,5 & 0445 \\
\hline 4. & Kancungan sulkur & $8 \mathrm{~m} / \mathrm{m}$ & & 035 & 02622 \\
\hline 5 & Distilys: & ${ }^{2} \mathrm{C}$ & & 370 & DB6 \\
\hline 6. & This myala & ${ }^{2} \mathrm{C}$ & 52 & & D.93. \\
\hline 7. & Thik fuang & $\mathrm{C}$ & & 18 & 0.97 \\
\hline 8. & Residukarben & Smim & & 0,1 & 04538 \\
\hline 9. & Kankungan air & Hoing & & 510 & 06354 \\
\hline 10. & Bislogiza grost & - & & & \\
\hline 11. & Kandungan FAllE & "givir & & & \\
\hline 12. & Kantungan metand & Yvity & Takb & Setess: & 04815 \\
\hline 13 & Korosi blah lembaga & Merit & & Kelas 1 & 0130 \\
\hline 14. & Kansungan Abu & Fen/y & & 001 & 0452 \\
\hline 15. & Kancungan secime? & $\mathrm{gm} / \mathrm{m}$ & & 0.01 & 0473 \\
\hline 16. & Blangas asam buat & ngkOHigr & & 2 & 0664 \\
\hline 17. & Blangan asan tobal & ngKOHigr & & 0,6 & D664 \\
\hline 16. & Partisulat & MgI & & & 0227 \\
\hline 19. & Penampilan nisual & & Jernih & nlerang & \\
\hline 20. & Warna & No.ASTM & & 3,5 & 01500 \\
\hline 21. & Lubricity & Micren & & 450 & 06079 \\
\hline
\end{tabular}

\section{RESULT AND DISCUSSION.}

3.1 Type of Damage of High-Pressure Pump

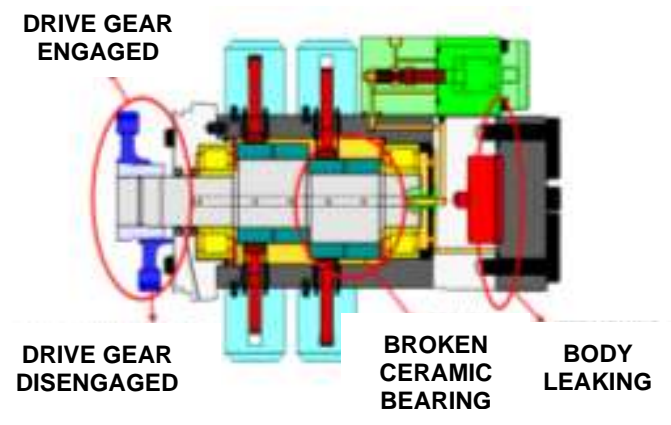

Figure. 3 Type of damage of the HighPressure Pump

a. Disengaged Gear Position

If we see damage to the MTU 4000 series High-Pressure Pump engine, then the Disengaged Gear Position or shifting of the drive gear is actually quite common. This is because if we view the safety system on the High-Pressure Pump MTU 4000 series engine itself, then the process of disengaged gear position is one part of the safety system itself, where when there is a problem or damage to the HighPressure Pump, it will occur the process of disengaged gear position, which is a process of shifting the drive gear HighPressure Pump (disengaged) to the engine gear so that there is no damage to the engine gear.

b. Ceramic Bearing Damage

One part that is quite vulnerable to damage in the High-Pressure Pump MTU 4000 series engine is ceramic bearings. This is because this part is one part of the 
High-Pressure Pump that is lubricated, whereas as I have told you, the HighPressure Pump MTU 16 V 4000 M 90 uses lubrication from the fuel itself. We can imagine if the fuel that enters the HighPressure Pump contains both dirt and water, then dirt and water mixed with fuel are pressed at a pressure between 700 bar to 1400 bar, and of course this can damage the ceramic bearing components.

c. Leakage on the Connection Between the Pump Body (Body Leaking)

Among the damage that occurred in the High-Pressure Pump MTU 4000 series engine, this type of damage is the most common damage. The cause of leakage between the High-Pressure Pump bodies is due to pitting corrosion on the surface of the plate. This event can be caused by water entering with fuel into the High-Pressure Pump so that it can cause pitting corrosion at one or several points at the connection of the two High-Pressure Pump bodies. At first the pitting corrosion is small but due to HighPressure up to 1400 bar, the pitting corrosion then extends and eventually can cause leaks in the connections between the body High-Pressure Pump.

\subsection{Fuel Composition}

Based on the results of the fuel composition test at Labinkimat, Fuel and Lubricant Laboratory (BBMP) Surabaya, the following fuel composition results are obtained:

Table 2. Water Content Table

\begin{tabular}{|c|l|c|}
\hline No. & Type of fuel Sample & $\begin{array}{c}\text { Water } \\
\text { Content } \\
(\% \text { Vol) }\end{array}$ \\
\hline 1. & $\begin{array}{l}\text { Fuel sample from } \\
\text { Bunker (Bunker } \\
\text { PERTAMINA) }\end{array}$ & 0,05 \\
\hline 2. & $\begin{array}{l}\text { Fuel sample from } \\
\text { PERTAMINA Pipe System }\end{array}$ & Nil \\
\hline 3. & $\begin{array}{l}\text { Fuel sample from Main } \\
\text { Tank }\end{array}$ & 0,015 \\
\hline 4. & $\begin{array}{l}\text { Fuel sample from Daily } \\
\text { Tank }\end{array}$ & 0,0001 \\
\hline
\end{tabular}

\section{Water Content}

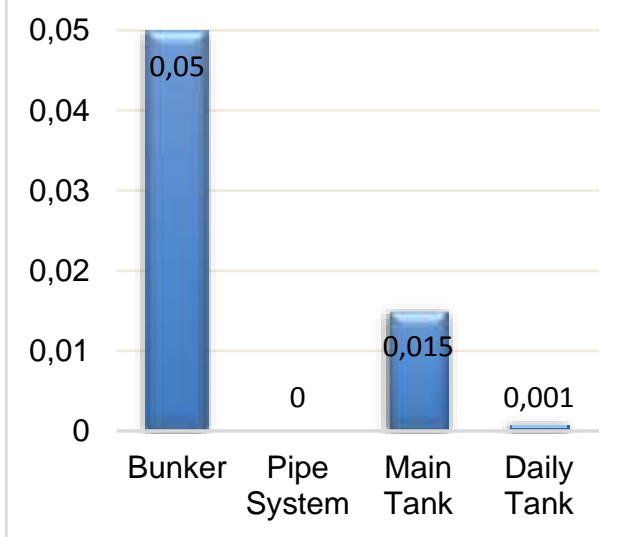

Figure 4. Water Content Chart

Water Content is the water content contained in diesel fuel. Water itself is one of the enemies of the Diesel engine and diesel fuel itself. High water content will cause the formation of crystals in the solar fuel system which consequently can block the flow of fuel so that the quantity of diesel fuel that will be injected into the combustion chamber will decrease so that there will be incomplete combustion in the combustion chamber and create black smoke in the chimney. Safe content limit for Water Content that has been set by PT. PERTAMINA is $500 \mathrm{mg} / \mathrm{kg}$, if it exceeds that number the combustion cycle will not experience complete combustion.

Table 3. Ash Content Table

\begin{tabular}{|c|l|c|}
\hline No. & Type of fuel Sample & $\begin{array}{c}\text { Ash } \\
\text { Content } \\
\text { (\% Wt) }\end{array}$ \\
\hline 1. & $\begin{array}{l}\text { Fuel sample from } \\
\text { Bunker (Bunker } \\
\text { PERTAMINA) }\end{array}$ & 0,01 \\
\hline 2. & $\begin{array}{l}\text { Fuel sample from } \\
\text { PERTAMINA Pipe } \\
\text { cuntom }\end{array}$ & Nil \\
\hline 3. & $\begin{array}{l}\text { Fuel sample from Main } \\
\text { Tank in KRI KLB-826 }\end{array}$ & 0,020 \\
\hline 4. & $\begin{array}{l}\text { Fuel sample from Daily } \\
\text { Tank in KRI KLB-826 }\end{array}$ & 0,0005 \\
\hline
\end{tabular}




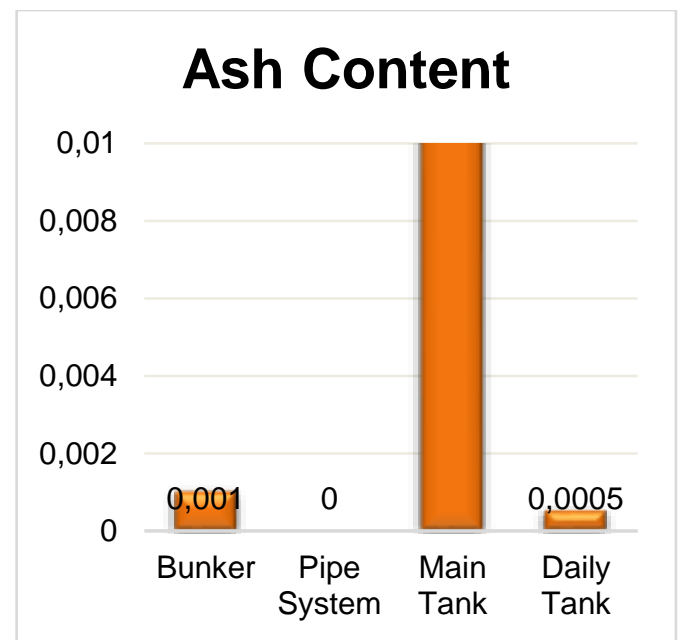

Figure 3. Ash Content Chart

Ash content is dirt in the form of ash in the system of diesel fuel. This impurity can affect the quality, because it can lead to failure in an operation and damage the engine. For that the smaller the dirt inside. The more fuel the diesel fuel has, the better the quality of the fuel. Ash Content Standards allowed in Solar Fuel is Ash Content, ASTMD 482.

When the ash content values are too high, it causes a blockage at the tip of the injector, because the formation of a temporary deposit of abrasive solids from this compound will cause the fuel injection component to wear out and the fuel filter becomes clogged so the quantity of fuel that is sprayed decreases.

Table 4. Sediment Content Table

\begin{tabular}{|c|l|c|}
\hline No. & $\begin{array}{l}\text { Type of fuel } \\
\text { Sample }\end{array}$ & $\begin{array}{c}\text { Sedimentation } \\
\text { Content } \\
\text { (\% Wt) }\end{array}$ \\
\hline 1. & $\begin{array}{l}\text { Fuel sample } \\
\text { from } \\
\text { Bunker (Bunker } \\
\text { PERTAMINA) }\end{array}$ & 0,005 \\
\hline 2. & $\begin{array}{l}\text { Fuel sample } \\
\text { from } \\
\text { PERTAMINA }\end{array}$ & 0 \\
\hline 3. & $\begin{array}{l}\text { Fuel sample from } \\
\text { Main } \\
\text { Tank }\end{array}$ \\
\hline 4. & $\begin{array}{l}\text { Fuel sample from } \\
\text { Daily } \\
\text { Tank }\end{array}$ & 0,01 \\
\hline
\end{tabular}

\section{Sedimentation Content}

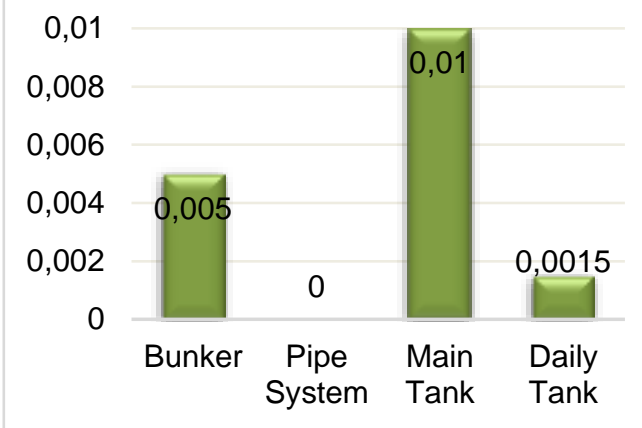

Figure 4. Sedimentation Content

The high number of sediment content in a fuel is very dangerous and really very worried. This is because high sediment content in a fuel will clog the fuel filter. In addition, sediment content can also be obtained forms deposits in the injection system or inside chambers combustion. And while the fuel oil is burning, these deposits will burn, then produce a deposit (deposit) in cold state. On the other hand, sedimentation levels are too high the fuel tank also results in sludge deposition high in the tank. And things you can do to overcome this is by carrying out tanks cleaning.

From the chart above we can see that 3 samples namely, fuel samples from the barge, main tank and daily tank have very high levels of sediment, even exceeding the allowable tolerance limits. This is possible because the fuel source from the barge which has high levels of sediment enters the fuel tank. Because this is constantly repeating so sediments occur at the base of the fuel tank, both the main tank and the daily tank.

Table 5. Sulphur Content Table

\begin{tabular}{|c|l|c|}
\hline No. & Type of fuel Sample & $\begin{array}{c}\text { Sulphur } \\
\text { Content } \\
(\% \mathbf{W t})\end{array}$ \\
\hline 1. & $\begin{array}{l}\text { Fuel sample from } \\
\text { Bunker }\end{array}$ & 0,0089 \\
\hline 2. & $\begin{array}{l}\text { Fuel sample from } \\
\text { PERTAMINA Pipe } \\
\text { Funtam }\end{array}$ & 0,140 \\
\hline 3. & $\begin{array}{l}\text { Fuel sample from Main } \\
\text { Tank }\end{array}$ & 0,0449 \\
\hline 4. & $\begin{array}{l}\text { Fuel sample from Daily } \\
\text { Tank }\end{array}$ & 0,0167 \\
\hline
\end{tabular}




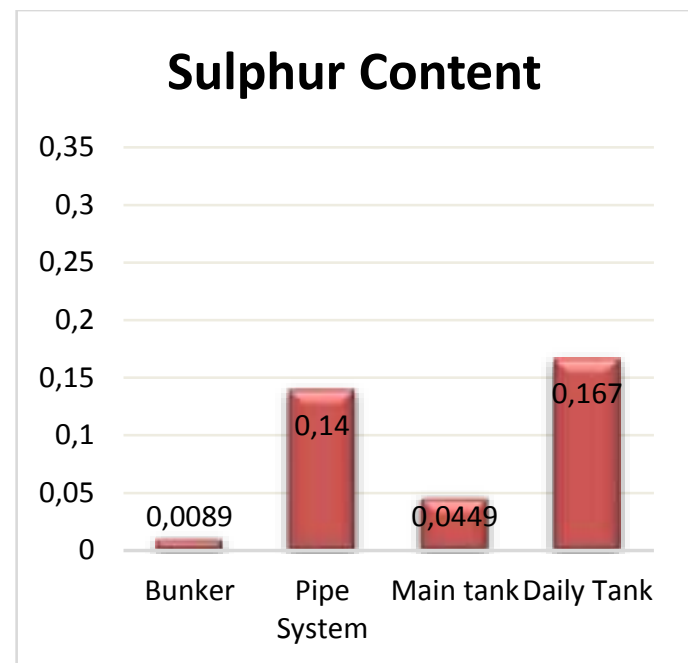

Figure 5. Sulphur Content Chart

In general, Sulfur content in diesel fuel is $50-60 \%$ of the content in crude oil. Sulfur in fuel oil can cause unpleasant odors, over a period of time it will create gum and sludge in its storage. In combustion will create smoke and corrode. Sulfur is the main enemy of diesel engines, because the higher the sulfur compounds in the diesel content, the excessive acid levels will occur so that the engine components and engine damage can occur. Crust in the fuel lines can disrupt the supply of diesel fuel flowed into the cylinder. The direct effect disrupts engine performance, ranging from a decrease in power to more serious damage, this is usually called premature combustion or Knocking. Sulfur content safe limit set by PT. PERTAMINA for PERTAMINA Dex diesel is $0.05 \% \mathrm{~m} / \mathrm{m}$ or equivalent to $500 \mathrm{ppm}$, if it is more than the safe limit then to achieve complete combustion will be less successful because too much Sulfur content can cause crust formation and clog the combustion system.

\subsection{Fuel Filtration System}

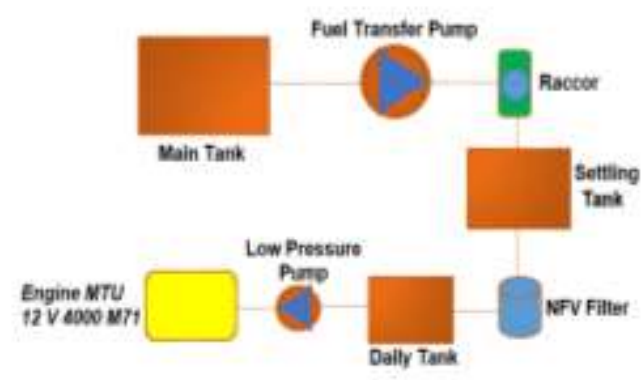

Figure 6. Fuel Filtration System

On the filtration system starts fuel from the main tank sucked up by the fuel transfer pump to the settling tank. On its journey the fuel will pass through raccor which serves as the first filtration device. Settling tank here functions as a clean tank which also serves as a temporary storage tank before the fuel will be sucked by the pump from the NFV filter to further undergo the filtration and coaliser process, where water and dirt will be separated by the NFV filter. After filtering on the NFV filter, the material will go to the tank daily to be collected before the fuel is sucked by the Low-Pressure Pump located in the MPK. Before entering MPK, the fuel will undergo the final filtration process in the fiber filter which is located just before the High-Pressure Pump.

\subsection{Maintenance System of Engine MTU 12 V 4000 M 71}

When we talk about the concept of maintenance on MTU machines, then of course on MTU machines use a preventive maintenance system. This is manifested in the levels of W1 to W6 which are implemented on MTU machines. This concept enables operational planning far ahead and ensures the availability of equipment very well.

Table 6. Maintenance Schedule of MTU 12 V 4000

\begin{tabular}{|c|c|c|}
\hline $\begin{array}{c}\text { Type of } \\
\text { Maintenance }\end{array}$ & $\begin{array}{c}\text { Maintenance } \\
\text { Frequency }\end{array}$ & $\begin{array}{c}\text { Running } \\
\text { Our Limit }\end{array}$ \\
\hline W1 & Daily & Daily \\
\hline W2 & 500 Hours & 6 Months \\
W3 & 1000 Hears \\
W4 & 5000 Hours & Years \\
\hline W5 & 7500 Hours & 6 Years \\
\hline W6 & 15000 Hours & 18 Years \\
\hline
\end{tabular}

Still related to the High-Pressure Pump maintenance schedule, this component is included in the repair volume of W5, where the work volume for this component will be replaced by 1 unit. For the set time for a single treatment of W5 alone is 7500 Play Hours. But in reality, on the ground, not yet up to the time of W5 treatment, the condition of the HighPressure Pump in KRI Kelabang-826 has been damaged. 


\subsection{Analysis}

Common rail technology is a
technology on engines that uses
configurations/ arrangements and components that are different from conventional fuel systems on other engines. One of the examples of engines that have implemented a common rail system is MTU. However, along with its development carried out rejuvenation in 2004 with MTU $12 \mathrm{~V} 4000 \mathrm{M} 71$ diesel engine as one of the products of MTU. Where this system relies heavily on a High-Pressure fuel pump that is able to provide a continuous supply of fuel at injection pressure to all injectors. In this common rail system does not require a component injector pump with a separate plunger which is driven by cam driven to produce fuel pressure to the entire injector. Where in timing and fuel capacity (fuel quantity) is set by the Engine Control Unit (ECU).

The pump has a vital function because it is able to supply fuel up to a pressure of 1400 bars on the common rail. The problem is that when there is a problem or the pump is damaged (leaking), the fuel pressure on the High-Pressure Pump input drops and of course impacts the HighPressure Pump's output fuel pressure towards the common rail, where the pressure drops dramatically, so that the fuel pressure is below 4 bar or fuel pressure inside the common rail below 700 bar Engine Control Unit (ECU) instructs the engine to do an engine stop.

There are several problems that often occur in the MTU High-Pressure Pump Engine 4000 series. These problems include shift gear drive (Armed Gear Position), damage to the ceramic bearing (Broken Ceramic Bearing) and leakage on the connection between the pump body (Body Leaking).

And from the author's observation, the most important thing that caused the damaged of the High-Pressure Pump under the life time are about the fuel quality. Faults of the common rail fuel system often result in loss of fuel pressure and causing the engine to cut out. Fuel Quality resulting in contamination of filters causing flow restriction.

a. Incorrect Fuel used causing damage to system components. Particularly, when a driver has accidentally refueled with petrol instead of diesel.

b. Electrical wiring, Sensor and Actuator faults. c. Most common rail fuel systems use a fuel accumulator rail mounted pressure sensor which will provide an electrical feedback signal to the engine management controller.

A loss of fuel pressure or a deviation from the desired amount of fuel pressure may be interpreted as a fuel system leak by the engine management controller in which case total system shut down may occur as a safety feature. Certain electronic management systems can lock out and prevent engine start until faults have been repaired.

In several sources and experiences that occur, the common rail fuel system always experiences problems when faced with poor fuel consumption. According to author observation in KRI Kelabang-826, some factors that can make the damage of the High-Pressure Pump MTU 12 V 4000 M 71 are:

a. Dirty fuel.

b. Contaminated fuel.

c. Fuel with certain chemical/ bio chemical composition

From some of these causes, it can cause several problems in the HighPressure Pump component, including:

a. Causing blockages in components.

b. Causes blockage to the system (all components).

c. Causing rusting/ cavitation of components.

d. Causes damage to components.

For the long-term effects of damage to the components of the High-Pressure pump can cause several problems, including:

a. Fuel pressure is not maximal.

b. MPK fuel system damage has occurred.

c. Ship Speed will not be fulfilled

So, the dirty and contaminated diesel fuel is a major weakness of the common rail system that uses High-Pressure Pump as its main tool. From that problems so we have to do some efforts and preventive ways in order to avoid the damage of the High-Pressure Pump Engine MTU $12 \mathrm{~V}$ $4000 \mathrm{M} \mathrm{71}$. And the efforts that can be made are:

a. Choose a good refueling source

b. Repair the fuel filtration system

c. Carry out tank cleaning regularly

\section{CONCLUSION.}

From analysis and discussion that has been done in previous chapters, some conclusions can be made as follows: 
a. KRI Kelabang-826 has poor fuel quality and fuel filtration system. This is evidenced by the results of fuel quality tests conducted at Labinkimat Lubricants and Oils Laboratory (BMMP), Surabaya. Where from the test results it was found that the fuel in the main tank and daily tank contained water content, ash content and sediment content which was high enough to damage the High-Pressure Pump MTU 12 V 4000 M 71.

b. High-Pressure Pump MTU 12 V 4000 $M 71$ is unrepairable and remanufacture, so it means it must be changed by the new one.

c. Poor fuel can shorten the life time of a High-Pressure Pump, whereas a good fuel can extend the life time of a High-Pressure Pump.

\section{ACKNOWLEDGEMENT.}

The author would like to extend her gratitude to Commanding officer of Naval Technology College who has given opportunity to collect data of my paper. The author would also like to say thank to Mr. Semin Mr. Wawan and Mr. Okol who have supported me in arranging and finishing this paper.

\section{REFERENCES}

Anjas, R. 2017, July 15. Definition of Diesel Fuel. Retrieved from http://prosesindustri.com/2015/02/ definition of diesel fuel diesel.html

Anto, R. 2015, April 5. Common rail diesel engine. Retrieved from porosengkolmania.blogspot.com: http://porosengkolmania.blogspot.co m/2015/ 04/diesel-common-rail.html

Detroit Diesel, C. 2001. Detroit Diesel Technician's Guide. Daimler Chrysler Company.

Hidayat, R. I. 2006. Livret KRI Kelabang826. Jakarta: Indonesian Navy.

Livret KR I Kelabang-826, 2006. Revision 1. Patrol Ship Unit of the Eastern Indonesian Fleet Command. Surabaya, Indonesia.

Pertamina. 2005. Retrieved from http://www.pertamina.com.
Simpelmenarik.blogspot.com.

2017

March Knowing Crude Oil, Solar, Gasoline and Kerosene. Retrieved https://simpelmenarik.blogspot.com /2017/2017/03/ knowing-oil-crudesolar-gasoline.html 